\title{
Paleohydrological reconstruction of molasses sediments from the Siwalik Group along Surai Khola section, West Nepal Himalaya
}

\author{
Prakash D Ulak \\ Department of Geology, Tribhuvan University, Kathmandu, NEPAL \\ For correspondence, E-mail: pdulak@wlink.com.np
}

The Siwalik Group is limited by the Main Boundary Thrust (MBT) to the north from the Lesser Himalaya and the Main Frontal Thrust (MFT) or equivalent to the Frontal Churia Thrust (FCT) to the south from Indo-Gangetic Plains. About six kilometres thick Neogene molassic mudstone, sandstone and conglomerate of the Siwalik Group is accumulated along the Surai Khola area in west Nepal in the southern frontal area of the Himalaya. The group comprises many fining-upward successions on a scale from several to tens of metres, but is a coarsening-upward succession as a whole.

Eight representative facies associations have been mainly recognized on the basis of the grain size of sandstone and assemblage of sedimentary structures in this sequence. These facies associations are intimately related to each lithological unit (Nakayama and Ulak 1999). According to them, the Bankas Formation and the Jungli Khola Member of the Chor Khola Formation are correlated to the Lower Siwaliks and are products of fine-grained meandering fluvial system. The Shivgarhi Member of the Chor Khola Formation and lower part of the Surai Khola Formation are correlatable to the Middle Siwaliks and, are deposited by the flood flow-dominated meandering fluvial system and sandy meandering fluvial system whereas the middle and upper parts of the Surai Khola Formation (Middle Siwalik) is produced by the braided fluvial system. The Dobata Formation (Upper Siwaliks) is represented of the product of anastomosed fluvial system. The lower and upper parts of the Dhan Khola Formation (Upper Siwaliks) are deposited by the gravelly braided fluvial system and debris flow-dominated braided fluvial system.

Nakayama and Ulak (1999) recognised five stages during the deposition of the Siwalik Group. They concluded the evolutional pattern of 6 stages which are from meandering system (stage 1), flood flow-dominated meandering system (stage 2), sandy braided system (stage 3), anastomosed system (stage 4), gravelly braided system (stage 5), and debris flow dominated braided system (stage 6). They inferred that three of the five stages are controlled by thrust activities; the onset of the deposition of the Siwalik Group by the Main Central Thrust (MCT), the gravelly facies of the lower part of the Dhan Khola Formation (Upper Siwaliks) by the Main Boundary Thrust (MBT), and the debris facies of the upper part of the Dhan Khola Formation (Upper Siwaliks) by the Central Churia Thrust (CCT) is equivalent to the Main Dun Thrust (MDT).

The paleohydrology and its evolutional change of the group along have been estimated using grain size of the sediment and thickness of fining-upward successions. Samples for grain size analysis were collected from the bottoms of the fining-upward cycles on a scale from several to tens of metres. The bottom of the fining-upward cycle is suitable sampling position for paleohydrological estimation. Forty-eight samples are obtained from twenty-two sections. Thin section and sieving methods are used for grain analyses because the consolidation of samples widely varied from strongly lithified to loosely packed. Both methods are explained in Tucker (1988). More than 200 of longest apparent grain dimension were measured in one section, and determined the mean of dimension, $50 \%$ dimension, and $95 \%$ of dimension, as mean diameter, median diameter, and $95 \%$ of grain size distribution, respectively.

Thickness between the top of bedload beds and sampling horizon is used for paleoflow depth. Most of the samples were obtained from the bottoms of the fining-upward cycles, so that bedload thickness is frequently concordant with flow depth. This is the extended application of the bankfull flow estimation in meandering channel (Ethridge and Schumm 1978, Bridge 1978). The estimation method in this study covers with both sandy and gravelly sediments, and also applicable to the outcrops with the limited lateral-dimension.

Paleovelocity varies from $0.17 \mathrm{~m} / \mathrm{s}$ to $3.28 \mathrm{~m} / \mathrm{s}$ stratigraphic upward, paleochannel gradient, and paleodischarge changes from $10^{-6}$ to $10^{-3} \mathrm{~m} / \mathrm{m}$ and $10^{1}$ to $10^{4} \mathrm{~m}^{3}$. The paleohydrology shows an increase in flow velocity, channel slope gradient, and paleodischarge in stratigraphic younger sequences and suggests gradually change in fluvial system during the deposition of the Siwalik Group. Relation between gradually change in the evolution of the fluvial system and the progressively increasing in paleohydrological parameters from older to younger of the stratigraphic position along the Surai Khola section, the Siwalik Group has shown coincidence.

The changes of paleohydrology reflect the southward propagation of thrust. Two drastic paleohydrological changes in this study is coincide with the inception stage 4 and stage 5 . That is, paleohydrological values change must reflect the southward progradation of thrust activities.

The Siwalik Group indicated the coarsening-upward as a whole, which has been simply considered to reflect the upliftment Himalaya. However, this study indicates that the Siwalik sedimentation has also to be considered in the viewpoint of the proximity from the thrust-formed piedmont line.

\section{References}

Nakayama K and PD Ulak. 1999. Evolution of fluvial style in the Siwalik Group in the foothills of the Nepal Himalaya. Sedim Geol 125: 205-224 Tucker M. 1988. Techniques in Sedimentology. Oxford: Blackwell, 394 p.

Ethridge FG and SH Schumm. 1978. Reconstructing paleochannel morphologic and flow characteristics: methodology, limitations and assessment. In: Miall AD (ed), Fluvial Sedimentology. Canadian Soc Petrol Geol Mem 5: 703-721

Bridge JS. 1978. Paleohydraulic interpretation using mathematical models of contemporary flow and sedimentation meandering channels. In: Miall AD (ed), Fluvial Sedimentology. Canadian Soc Petrol Geol Mem 5: 723-742 